\title{
Ras-Related Protein Rab-8A
}

National Cancer Institute

\section{Source}

National Cancer Institute. Ras-Related Protein Rab-8A. NCI Thesaurus. Code C17696.

Ras-related protein Rab-8A (207 aa, $\sim 24 \mathrm{kDa}$ ) is encoded by the human RAB8A gene.

This protein plays a role in the modulation of intracellular membrane trafficking. 